Most of the information concerns the State of Minas Gerres, Brazil, where Rocky Mountain spotted fever has apparently existed for some time. There are four clinical forms of the disease: inapparent, mild, malignant and fulminating. It seems that there is only one virus, but probably there are various strains which may be differentiated by proper tests. The epidemiological nature of the infection in some regions of Minas Geraes is quite different from that of Rocky Mountain spotted fever in the United States.

\section{Tables of Bessel Functions}

The Committee on Mathematical Tables of the U.S. National Research Council was advised that there was a great need for a modern "Guide to Tables of Bessel Functions", as there is scarcely a single field of applied mathematics in which these functions are not used. After more than a year of preparation, this "Guide" was compiled by Profs. H. Bateman and R. C. Archibald, using material on which the former had been working for many years, and has been published as a special number, occupying 104 pages, of the journal Mathematical Tables and other Aids to Computation $(1,205$; 1944. Washington, D.C. : National Research Council. 1.75 dollars. London: Scientific Computing Service, Ltd. 10s.). There are two parts, one in which tables and graphs are listed with their authors, and another consisting of an alphabetical bibliography of the authors. In some places there are important formulæ with explanations of how to use them. The notation has been chosen so as to agree so far as possible with that used by English authors. In addition to giving full references to all published tables of Bessel functions, the authors endeavoured to add details of every known unpublished table, but unfortunately the comprehensive Liverpool "Index of Mathematical Tables" prepared by A. Fletcher, J. C. P. Miller and L. Rosenhead was not available, even in proof, until it was too late to give more than a cursory reference, and it was then found that the "Index" referred to more than thirty manuscript tables unknown to the "Guide". The second edition of Watson's "Bessel Functions" appeared too late to be mentioned. A valuable feature of the "Guide" is the information concerning all known errors in the tables mentioned. A number of errata lists appear in print for the first time.

\section{Radiant, Dielectric and Eddy-Current Heating}

A PAPER on the place of radiant, dielectric and eddy-current heating in the process-heating field was read recently in London before the Institution of Electrical Engineers by Messrs. L. J. C. Connell, O. W. Humphreys and J. L. Rycroft, in which the authors maintain that if the fullest advantage is to be gained from the rapid developments which have taken place in connexion with radiant and high-frequency methods of heating, care must be exercised in the selection of the applications for which they are recommended. Although many processes can be carried out more effectively by the new methods, there is still a very real place for contact and convective heating. The purpose of the paper is to facilitate this selection. The paper first reviews the various methods of heating, indicating the physical laws and practical considerations by which they are governed and the rates of heating which may be obtained. The types of application for which each process is best suited are then classified in terms of their technical requirements. Finally, several applications are considered in some detail, and it is shown that processes having superficial similarity may nevertheless possess features, not at first apparent, which are of sufficient importance to warrant the use of different methods of heating.

\section{The Earthquake at San Juan, January 15, 1944}

Horacto J. Harrington, professor of geology at the University of Buenos Aires, has described some of the effects of this earthquake ("El Sismo de San Juan del 15 de enero de 1944", Cienciae Investigación, Jan. 1945). The shock occurred at 19h. $46 \mathrm{~m}$. 29 s. without any previous warning and attained a maximum intensity in a few seconds, ending suddenly about 15 seconds after the first shock. The first shock was from below upwards, and in a few seconds afterwards a new shock took place in a horizontal direction and of an undulatory nature, from west to east. When the tremors had ceased, some 90 per cent of the buildings in San Juan had been totally or partially destroyed. The depth of focus was $14 \mathrm{~km}$., with a probable error of $3 \mathrm{~km}$., and the epicentre included the zone extending north from San Juan to Chimbas and Albardon. The intensity of the San Juan earthquake was ix on Sieberg's scale, and so was not excessive; nevertheless the destruction was very much greater than would have been expected. Out of a total population of seventy to eighty thousand, about eight thousand were killed and twelve thousand injured; the disproportion between the intensity of the earthquake and the destruction effected is obvious. The loss of life in the San Juan earthquake was due to the buildings being made with unbaked bricks of clay; these should be avoided in reconstruction. In addition, many of the cities of the country are built at the foot of high mountain ranges, and zones of fracture render their existence more or less precarious.

\section{Announcements}

Sir JACK DRUMmond, chief scientific adviser to the Ministry of Food, has been appointed to the post of director in charge of the whole of the scientific research of Boots Pure Drug Co., Ltd. Sir Jack Drummond has resigned the chair of biochemistry at University College, London, which he has held since 1922, but he will not take up his new appointment until the food situation has improved.

THE Council of the University of Sheffield has accepted a gift of $£ 1,000$ from Dr. S. B. Bagley, chairman of the Glass Delegacy, to provide a fund for research purposes within the Department of Glass Technology.

The Medical Research Council has offered to establish a Biochemical Research Unit in the University under the direction of the professor of biochemistry, and the University Council has accepted the offer.

The Council has made the following appointments : Dr. B. M. Laing, at present lecturer in charge of the Department of Philosophy, to the newly instituted chair of philosophy; Major F. W. Shotton, to the chair of geology in succession to Prof. W. G. Fearn. sides, on the retirement of the latter; Mr. A. M. Woodward, at present lecturer in charge of the Department of Ancient History, to be reader in ancient history and archæology, and head of the Department of Ancient History. 